\title{
THE TRANSNATIONAL TEXTILE COMPANIES RELATIONSHIP WITH ENVIRONMENT: A DELPHI ANALYSIS APPROACH
}

Relación de las empresas transnacionales textiles con el ambiente a través de un analisis Delphi

$$
\text { Arturo LUQUE GONZÁLEZ }{ }^{1 *} \text { and Juan HERNÁNDEZ ZUBIZARRETA² }
$$

\author{
${ }^{1}$ Universidad Técnica de Manabí, Ave. José María Urbina y Che Guevara, Portoviejo, Manabí, Ecuador and \\ Euro-Mediterranean Observatory on Public Policies and Democratic Quality, Universidad Rey Juan Carlos, \\ Paseo de los Artilleros 38, 28032 Madrid, Spain \\ ${ }^{2}$ Institute for International Cooperation and Development Studies, Hegoa, University of the Basque Country \\ (UPV/EHU), Ave. Lehendakari Aguirre, 81, 48015 Bilbao, Spain \\ *Corresponding author: arturo@elcandelero.es
}

(Received: March 2017; accepted: March 2018)

Key words: globalization, corporate social responsibility, transnational firms

\begin{abstract}
The main purpose of this article is to analyze from a quantitative perspective, the textile transnational corporations (TNC) relationship with environment through a Delphi analysis. Our analysis has been applied with two panels composed of 55 experts with two multidisciplinary questionnaires with open questions, regarding the degree of affinity (test) to the proposals made. The presentation of the results obtained shows the lack of ethics on the part of companies within their relation with the environment. The incessant appropriation of natural resources but not of their impacts and sequels as well as the lack of diligence when pursuing environmental crimes bring out the delicate situation between the ETN and everything that stands in the way of their interests. Hence, it is necessary to know the risks and relationship of corporate social responsibility from a scientific methodology in order to reflect and modify future behaviors by production companies when interacting with the natural environment and assume real responsibilities through the proposal of action guides presented here.
\end{abstract}

Palabras clave: globalización, responsabilidad social corporativa, empresas transnacionales

\section{RESUMEN}

El objetivo de esta investigación es analizar desde una perspectiva cuantitativa la relación que tienen las empresas transnacionales (ET) textiles con el ambiente a través de un análisis Delphi. Se han estudiado las respuestas de dos paneles de 55 expertos por medio de cuestionarios multidisciplinares de preguntas abiertas, atendiendo al grado de afinidad (prueba) de las proposiciones planteadas. La presentación de los resultados obtenidos evidencia la falta de ética por parte de las empresas en su relación con el ambiente. La apropiación incesante de recursos naturales pero no de sus impactos y secuelas así como la falta de diligencia a la hora de perseguir delitos ambientales ponen de manifiesto la delicada situación existente entre las ET y todo lo que se interpone a sus intereses. De ahí que sea necesario conocer los riesgos y su relación con los procesos de 
responsabilidad social empresarial desde una metodología científica con la finalidad de reflexionar y modificar futuras conductas por parte de empresas productoras a la hora de relacionarse con el entorno natural y asumir así responsabilidades reales mediante la propuesta de guías de acción aquí presentadas.

\section{INTRODUCTION}

The international the textile industry has transformed. According to Lipovetsky (2013): "Today, fashion is not only an aesthetic and peripheral luxury of collective life, but has become a central element of a social process which governs the consumption of objects". This statement can be understood from different perspectives, such as haute couture or the analysis of cyclopean and asymmetric global production chains that enable textile production at low cost (ILO International Labor Organization, 2015) where, according to the United Nations Economic Commission for Europe UNECE (2018), "one out of every six people in the world works in a job related to fashion, and $80 \%$ of the workforce in the entire supply chain are women." In many cases, these production chains pivot on the lack of both human rights (HRs) and opportunities for the workers in these chains (Human Rights Watch 2015). According to a report by Oxfam Intermón (2016, p.6), “Textile companies invariably take advantage of their position of strength to continue paying poverty wages", in addition to being the worst industries in the world in relation to the environmental pollution they produce (Kant 2012).

The impact of the textile transnational corporations (TNC) on the environment is inherent to their industrial activity (Vandevivere et al. 1998, Pinheiro et al. 2004), while they run concurrent impact programs based on corporate social responsibility (CSR) policies in a continuous attempt to make the brands be, and seem, sustainable. It should be highlighted that a lack of legislation in many of the producing countries and their weak regulations facilitate global textile production. For textile TNCs, it is always better to direct the market themselves, with voluntary improvements and sanctions through CSR policies, rather than via strong mandatory legislation verified by the public authorities. Nobody likes to be told what to do, and TNC even less (Luque et al. 2016b).

Professors Donaldson and Dunfee (1999), in their Integrative Social Contracts Theory, show multina- tionals the way, indicating that they are also moral agents and act as people, and should contribute to the well-being and harmony of the place where they carry out their industrial activity, despite choosing production sites in locations with weak legislation (Rhodes 1997). In relation to this issue, the researcher from the Institute of Molecular Biology, IBMCP, Mulet (2015) indicated that, "With respect to third countries, European companies benefit from non-existent environmental legislation. Is that ethical? I think it is not, but it is a political problem, not a scientific one."

It is important to differentiate what a company must do, or what the law forces them to do, and what they really do. For Dussel (2015), "labor and environmental legislation varies by country and even within countries (for example, in the United States). My impression is that the best legislation - at least as an incentive - comes through clients: by them demanding that the entire chain meets specific demands." There is, therefore, the need to develop a study that will enable us to understand, in a reasoned manner, the transversality and interconnection of the situations described above. We will do this thanks to 55 experts ${ }^{1}$ who present their academic discussion and analysis of concepts, by obtaining consensus among all the participants, and thereby increasing the reliability of the study object (Dalkey and Helmer 1963). In addition, a set of action guidelines is presented aimed at civil society, institutions, and the textile industry, to reduce the impact of production on the environment and generate consumption with greater guarantees.

According to the European Commission (2013) the textile industry is one of the largest and most polluting in the world, in addition to using chemical substances that have devastating consequences for both the environment and people (Chen and Burns 2006, Gallezot 2012, Oliveira et al. 2013, Browne 2015). In fact, due to the consequences of pollutants produced by the textile and tannery industry in Bangladesh, it is the first time in history that Doctors Without Borders have intervened in a

\footnotetext{
${ }^{1}$ The list of experts and their institutions is presented in Annex I, at the end of the article.
} 
country for reasons other than war or natural disasters (Muralidhar et al. 2017). In addition, "apart from heavy metals such as chromium, cadmium, lead, and mercury, a conglomerate of chemical products is discharged by tanneries into the environment." We should remember that these circumstances lead to chronic dermatological and pulmonary diseases. The toxicity generated impacts freshwater, people, and both marine and terrestrial ecosystems, and it is necessary to exercise greater control over regulation of colorants and additives (Yuan et al. 2013). According to Luongo (2015, p.37) "It has been shown that these two groups of compounds [quinolines and benzothiazoles] released during clothes laundering are discharged into domestic wastewater and later into the aquatic environment [...]". At the same time, about 100 different chemical compounds have been identified in textiles that present risks including skin irritation, reproductive toxicity, and carcinogens (US Occupational Safety and Health Administration -OSHA-, Jadhav et al. 2010)

We should note this emerging hidden damage in textile garments due to different agents responsible for various pathologies, like endocrine disruptors ${ }^{2}$. When Soriano (2015), head of the innovation area of the Spanish Textile Industry Research Association (Asociación de Investigación de la Industria Textil AITEX), was consulted about whether chemical dyes could release highly persistent and difficult-to-isolate pollutants, and if these would be stored in the fat of living beings once they had entered the food chain, she noted, "[...] these substances enter the food chain and pass from living organisms (fish) to living organisms (people) in a sudden way, producing irreparable short-term, and even medium- or long-term damage."

Other effects of textile production are energy consumption, photochemical pollution, and waste production (Labouze et al., 2006). Textile production processes increase the carbon footprint (Beton et al., 2014) as well as the water footprint (Chapagain et al., 2006), since huge quantities of water are required for making textile products. For Bevilacqua et al. (2011), the textile chain's main contribution to the greenhouse effect is through the consumption of electricity and thermal energy for transport. It is worth remembering the great degree of delocalization and the number of suppliers, aspects encouraged by companies searching merely for the best price and less control. In a similar way, they push the level of human rights down to reduce their costs, a situation that TNCs promote through enormous economic resources, influence, and corruption (Luque et al., 2017a).

In this case study, the central hypothesis examines the relationship of transnational textile companies (textile TNCs) with the environment through their corporate social responsibility (CSR). This is done by analyzing each of the questions presented to the experts, including the relationship of power over the existing natural resources - and the ruthless appropriation of these - necessary to develop production, as well as the effect of this industry on people ${ }^{3}$, living things ${ }^{4}$, and the natural environment.

\section{Environmental determinants}

Climate change is a reality that generates an amalgam of regulations and constant asymmetries. It is a real threat of limitless scope and consequences, many of which are unpredictable (others are predictable and evident), that alter production methods, societal biorhythms, and modify all types of ecosystems that are not precisely natural (Jacobson and Price, 1990; , Pawlik, 1991; , Dietz and Rosa, 2002; , University of Copenhaguen, 2009; , Ramonet, 2010; , IPCC, 2014). Climate change affects industrial developments and, implicitly, the choice of countries chosen for productive activity — with more lax legislation — as well as affecting the consumption model, since it is impossible to isolate this from the natural environment. According to Duarte (2014), a professor and researcher at the Mediterranean Institute of Advanced Studies, "There is no reasonable doubt about the influence of human activity on the global climate, nor about the fact that this influence has comprised an increase in

\footnotetext{
${ }^{2}$ Endocrine disruptors are a type of chemical compound that can upset the balance of the human body by preventing the endocrine system from working properly. Exposure to endocrine disruptors can occur when absorbing them through: 1) the skin when in contact with fabrics and soaps; 2) the lungs when breathing; 3) water that is drunk; and 4) foods that are consumed. Definition from the University of Michigan, 2012.

${ }^{3}$ According to the 6/14 report by the Swedish Chemicals Agency entitled "Chemicals in textiles: Risks to human health and the environment", $10 \%$ of the residues of substances that can be found in textiles can be considered a risk to health. On the other hand, $5 \%$ of those products are potentially damaging for the atmosphere.

${ }^{4}$ According to the researcher M. A. Browne, nearly $85 \%$ of the materials of human origin that can be found along the coasts are microfibers. From the document entitled "Sources and Pathways of Microplastics to Habitats" in the journal Marine Anthropogenic Litter. Springer International Publishing, 2/06/2015.
} 
the global average temperature." In addition to that described above, climate change generates further reasons for violent conflicts and new forms of wars (Welzer, 2009). According to a 2015 report $^{5}$ by the United Nations Economic and Social Commission for Asia and the Pacific:

During the first half of 2014, the highest number of storms in the last five years occurred in the Asia and Pacific regions. The number of storms increased by $70 \%$, with serious consequences in several countries such as Afghanistan, Bangladesh [in Bangladesh alone there are more than 4,500 textile factories], Cambodia, China, the Philippines, India, Myanmar, Pakistan, Sri Lanka, Vietnam, and the Pacific region. In Sri Lanka, for example, 22 of the 25 districts were affected by the severe flooding that touched approximately 1.1 million people.

Nowadays, it is not possible to hide behind certain obsolete industrial developments from the past, like the use of old and polluting machinery, while profiting from deliberately obsolete legislation, however profitable this may be for the interested parties (Human Rights Watch 2012). For Morin (2015, p.2):

Because humanity is currently threatened by deadly dangers (multiplication of nuclear weapons, unleashed fanaticism and the multiplication of internationalized civil wars, the accelerated degradation of the biosphere, crises, and imbalances in an economy dominated by unbridled financial speculation), the life of our species itself and, inseparable from this, the biosphere, become a primary value, an imperative priority.

The current economic model is based on perpetual growth. Its consequences enter via our windows - air quality and climatological effects derived from the global warming of the Earth-, our lungs via the air we breathe, legally contaminated (or unhealthy) products, inadvertent exposure to chemical substances, and so on. These situations truncate the population's life model, principally in the most disadvantaged regions. According to Stern et al. (1992), climate change is the most complex environmental threat humans have ever faced. According to the European Environment Agency, (EEA (2016), the effects of climate change produce extreme weather phenomena, such as increased global temperatures, the appearance of heat waves (augmenting health risks by increasing infectious diseases), intense rainfall, and more frequent droughts. It causes sea level rises, creates dead zones lacking oxygen, the Arctic sea ice and glaciers are reduced, as is the snow cover produced; it even increases plant life in Antarctica with dramatic effect (University of Exeter, 2017), impacting inexorably on terrestrial and marine biodiversity. For just the member countries of the European Environment Agency (2016), the effects deriving from climate change have meant financial losses of more than 400 billion euros since 1980. Climate change affects harvests, increases the displaced population, produces floods ${ }^{6}$, conditions the scarcity of water resources, and so on. According to UNESCO (2016, p.29), “[...] by the year 2050 between 150 and 200 million people could be displaced as a result of events such as desertification, sea level rise, and the increase of extreme weather events." Herring (2014), from Northeastern University, estimates that climate change will generate an increase in extreme cold waves in Europe and the USA. According to Jim Yong Kim, President of the World Bank Group, "Scientists tell us that if the temperature of the Earth increases by $2^{\circ} \mathrm{C}$-which can occur in 20 to 30 years - this phenomenon will cause widespread situations of food shortage, unprecedented heat waves, and more intense cyclones" (World Bank, 2013). According to a study by Kelley et al. (2015, p.1) "There is evidence that the 20072010 drought contributed to the conflict in Syria. It was the worst drought in the instrumental records, causing a generalized crop failure and a massive migration of farming families to urban centers. [...]". The situations described above are encouraged by the textile industry due to the high environmental impact of their activity (Herva et al., 2008), demonstrating the long shadow of progress behind many catastrophes, amplified by the unlimited hyper-consumption of textiles (Luque 2017b).

The companies of the future are those that have the greatest capacity to implement the correct balance

\footnotetext{
${ }^{5}$ Report of the Secretary-General for the strengthening of the coordination of emergency humanitarian assistance provided by the United Nations A/70/77-E/2015/64 of 04/17/2015 p.6.

${ }^{6}$ The Stern Report develops the economic consequences of climate change, studying the effects of a low-carbon economy as well as the efforts needed for adaptation; text by N. Stern commissioned by the UK government on 10/30/2006.
} 
between the rights and obligations of their workers - including the production line - together with a real environmental policy that goes beyond the meager current regulations. This includes generating competitive advantages through non-aggressive developments, an aspect highly valued by the consumers who reward or punish companies through their purchases. For this, it is necessary to prepare real forecasts of costs, consequences, and responsibilities in textile developments, such as, for example, pollution rates. According to Matthews (2015), "The United States is responsible for $40 \%$ of the global debt for climatic damage." It is appropriate to establish a replacement rate for direct and indirect damage caused to our natural environment deriving from industrial production. This must be implemented realistically and without subterfuge through impact action, in many cases under the umbrella of CSR action. Standing out by way of example are jobs related to climate change, adaptation to regulations, and the emergence of new consumption-related family and society models. For all these reasons, there should be an organizational transformation based on cultural change. We should point out the possibility that this could encounter resistance from certain agents with interests in working today as they did in the past, with no kind of environmental restriction and with maximization of profit as the business ideology, squeezing out any sustainability either through action or omission. For the Indian sociologist and former director of the Center for the Study of Developing Societies in New Delhi, Nandy (2015, p.1):

There is no environmental catastrophe for which there is not a lobby - political, scientific, or economic elites - that fences off the argument of progress to absolve the people responsible for the destruction they have caused. From Three Mile Island to Chernobyl, through Minamata, Bhopal, or Fukushima the same story is repeated. Progress is not an innocent idea. Now it is an ideology that people are willing to kill and die for.

According to McKinsey Quarterly (2007), only $23 \%$ of companies take into account the impact of climate change when choosing a provider. As an example, the Inditex textile TNCs has 6,000 suppliers working for them in more than 45 countries (Boix 2016). Consumers are unaware of the commitment of these companies and subcontracted workshops, with the environment. According to UNECE (2018):
The fashion or apparel industry has an oftenunderestimated impact on the development of our planet. This $\$ 2.5$ trillion industry is the second most intensive water user in the world, producing 20 percent of global wastewater. Producing a cotton shirt requires 2,700 liters, the same amount a person drinks in 2.5 years. $10 \%$ Ten percent of global carbon dioxide emissions are emitted by the textile industry, and cotton is responsible for $24 \%$ of the insecticides and $11 \%$ of the pesticides, despite using only $3 \%$ of the world's arable land.

\section{CSR and transnational textile companies}

According to the data published by the World Trade Organization (WTO, 2015), in just garments the sector generates exports of $€ 483$ billion (without counting other textiles that represent $€ 314$ billion); $€ 290$ billion of this is generated in Asia alone. This is an aspect known by the textile TNCss, and which they are not willing to let slip away from them. To this end, they articulate favorable legislation (including custom-made laws), carry out production in countries with high levels of corruption, and take advantage of weak working conditions in producing countries, many of which have anemic levels of ratification for ILO conventions (Luque, 2018). TNCss encourage a great deal of competition, even between the factories of identical brands in different countries fighting for the same order to push the price down. They create dependence in certain suppliers (monopsony), thereby increasing the power and decision control of the textile TNCs. This business model has the capacity to impose private dispute-resolution systems (arbitrations) between companies and States, conditioning investments while at the same time delegitimizing and minimizing the competencies of the indigenous courts by reducing the maneuverability of the States (Luque and de Pablos 2016a ). There is a continuous and systematic use of the environment that constantly degrades it, without the textile TNCs assuming the real consequences of this depletion, in addition to the effects deriving from textile production processes (Senthilkannan, 2015), despite all TNCs having voluntary improvement programs as part of their social responsibility policies.

This is the context in which the CSR policies that are to be analyzed were created and developed. Beginning in the 1990s, TNCs deployed and strengthened these practices with the aim of correcting abuses in their own global production chains by indirectly avoiding more rigid legislation and more ethical policies, transposing unilateral CSR measures. 
Despite involving millions of dollars, custom studies, favorable ideological currents ${ }^{7}$, business support of all kinds, certifications, books, lobbies, audits, impact campaigns, and so on (Smith, 2014), it is clear that this model has been a resounding failure due to unilateralism and lack of enforceability. According to Berrón (2015) “[...] corporate social responsibility works like a social wash or, in the best cases, it is implemented by companies that are already clean, in other words, those that by and large do not violate rights." Correctly managing CSR policies, without subterfuge, can help improve both the company's performance and its relationship with the other agents in continuous movement. For this, the first step must be strict compliance with the law, or this should be established in a solid, credible way using internationally recognized parameters where necessary, an aspect TNCs take advantage of for their own benefit. CSR is a complementary element and not a substitute for the law, bearing in mind what society expects through its actions (Rojas et al., 2006; , Costa, 2007,; Barroso, 2008).

\section{METHOD}

The Delphi method combined with an interview are the best tools for analyzing the relationship of textile TNCs, subsumed to processes of globalization in continuous movement, and the environment, from any perspective, including the empirical one (Martinez Piñeiro, 2003; , Landeta, 2006). It is important to understand the reality of the phenomenon as the transformation and evolution of the textile sector globally, with new methods of production, management, legislation, and so on, but at the same time including systemic deficiencies, such as industrial relationships with the environment, a situation that we should analyze in this study, using the Delphi technique (Ruiz Olabuénaga and Ispizua, 1989; , del Rincón, Arnal, Latorre, and Sans, et al. 1995). Changes in the business environment open society to new solutions (Applegate, 1994), a circumstance that creates a new paradigm to study.

\section{The Delphi method}

The Delphi method is a prospective technique that allows a consensus to be found through a set of key issues that have been put forward, in this case by two panels of experts based on the discussion of a specific problem. According to Martinez Piñeiro (2003, p.451) "the main aim of this technique is to find a consensus of opinion among a group relating to a specific problem, the solution to which and possible future situation is difficult to predict." Arias (2003) states that it is assumed that new, innovative research methods will emerge, enabling the development of new theories and challenging many of the current models, as well as providing different perspectives on a given contingency, even in areas of uncertainty or with little empirical evidence (Pill, 1971). For Linstone and Turoff (1975), it is a method for structuring a group communication process, which has an effective result when it comes to allowing a group of individuals, as a whole, to deal with a complex problem. According to Mengual (2011, p.146), a particular individual tends to have lower reliability than a homogeneous group of people in equal conditions, which is also, as Vélez Pareja (2002) points out, ideal for studying topics where obtaining information from both the past and the future is not clear. For Luna Huertas et al. (2006, p. 94) "The Delphi method, unlike other qualitative techniques like focus groups or nominal groups, allows information and opinions to be obtained from physically distant subjects, and enables the generation of ideas with open answers, in a well-structured way and with an added qualitative component."

\section{Process followed}

A research question was defined through a proposal. To this end, the related literature was analyzed in addition to the subject to be studied: "What is the relationship of textile TNCs with the environment, as well as their responsibility for this with relation to their production processes and the use of favorable legislation?" Next, experts were selected and recruited, based mainly on the literature review, and the questionnaire was constructed as an analysis tool. The questions in the questionnaire were determining, taking into account the narrowness of the subject, literature, current situation, as well as the transversal nature of the topic. Once developed, the questionnaires were sent to the participants. As indicated by Martinez Piñeiro (2003, p.452), "The researcher

\footnotetext{
${ }^{7}$ When injustice is business: How law firms, arbitrators and financiers are fuelling an investment arbitration boom text prepared by $\mathrm{P}$. Eberhardt and C. Olivet through Transnational Institute and Corporate Europe Observatory in Brussels/Amsterdam, November 2012, p. 9 states that: "Investment lawyers have a firm grip on academic discourse on investment law and arbitration, producing a large part of the academic writings on the subject, controlling on average $74 \%$ of editorial boards of the key journals on investment law..."
} 
draws up a second questionnaire based on the answers received, often with closed answers that allow the group responses to be analyzed statistically"; another round of questionnaires or additional training may be sent if necessary, or the surveys withdrawn when there is little consensus or when it is observed that this cannot be improved upon, as indicated by Fernández-Ballesteros (1995). There is, therefore, no fixed or preconceived number of consultations. In this case, the second round questionnaire was sent to all the participants whose answers did not reach a consensus.

\section{Questionnaire model}

The questionnaire is a crucial tool in the process, and serves to collect information with the aim of obtaining a consensus among the participants in each panel.

The project involved experts and researchers in fundamental rights, the chemical-epidemiological sector, production managers, logistics professionals, economists, legislators, transnational corporations, lawyers, NGOs, laboratories, scientific disseminators, and so on, so it was decided to narrow the subject areas into two panels of experts: one on CSR, management and ethics; the other on epidemiology, laboratories, chemical scientists, health, and the environment. In both, multidisciplinary and common questions were included in the questionnaires. The first contained 20 closed questions with a Likert scale of 1 to 7, as did the second, with the exception that 10 of the closed questions were common to both. In this work we show those where there was consensus. After the first round we analyzed the 20 different questions and the 10 questions common to both panels.

The data collection tool for the closed questions used a scaled response format with the aim of measuring attributes, benefits, or losses, with 20 statements on each questionnaire (considerably reduced for the second round due to the degree of consensus). The key read "Put a cross (x) in the box corresponding to your degree of agreement with the statements below, relating to the subject of this investigation", with 1 being total disagreement and 7 total agreement; participants could also leave comments on the statements. This Likert scale was used by Hamilton (1997), Patry et al. (1999), and Espino Rodríguez (2003), in various studies on externalization, for which reason we understand it to be a valid method for this work. According to Murry and Hammons (1995) it is the commonest tool for quantifying results in Delphi studies.
Subsequently and prior to the data collection process, consensus levels were established. This was $75 \%$ in three contiguous categories. In other cases, such as that of Martinez Piñeiro (2003) a consensus is understood as $70 \%$ affinity in at least two contiguous values on a scale of 1 to 5 , which is why a percentage agreement of $75 \%$ has been considered for three contiguous values when using a broader scale, from 1 to 7 , as there is greater dispersion. It should be considered that the accumulated percentages allow the level of consensus to be established for each of the questions.

\section{Collection process}

After the surveys had been sent and collected, between 01/05/2015May 1, 2015 and 07/30/July 30 , 2015 , of the 55 questionnaires received, only 12 were received in the second round; it was noted that these contained almost the same position as in the initial survey. Indeed, some people did not respond, as it was explained in the procedure that if they did not do this in the successive rounds, the initial assessments would be used. The data received was then quantitatively analyzed, as were the participants' observations and proposals.

Below is a detailed analysis of the data followed by the results obtained. Of the all statements developed and analyzed, we show those where there was consensus among the participating experts, the aim of the Delphi method (Landeta, 2002, 2006), and we also include quotes and relevant recommendations received from the experts.

Using the obtained data, a descriptive statistical analysis was carried out, which resulted in 6 six graphs from the two participant panels. We used the arithmetic mean (from 1 to 7), median, standard deviation, mode, and the inclusion of a graph of the results.

\section{RESULTS AND DISCUSSION}

The attitude of textile and chemical TNCs to the environment is inappropriate (Figs. $\mathbf{1}$ and 2). With respect to the information received and analyzed on the answers to the question "The attitude of-textile/chemical-companies to the environment is appropriate", according to the percentage of affinity collected, there was consensus among the participants when it came to tending against the proposal. The sum of the values with the highest affinity were 1, 2 and 3 , totaling $83.7 \%$.

The international expert in molecular biology and toxicology, Watson (2015), states, "It is sad to say 
The attitude of -textile/chemical- companies to the environment is appropriate

\begin{tabular}{|l|c|c|c|c|}
\hline & Freq. & Percentage & $\begin{array}{c}\text { Valid } \\
\text { percentage }\end{array}$ & $\begin{array}{c}\text { Accumulated } \\
\text { percentage }\end{array}$ \\
\hline 1 & 13 & 23.6 & 30.2 & 30.2 \\
\hline 2 & 16 & 29.1 & 37.2 & 67.4 \\
\hline 3 & 7 & 12.7 & 16.3 & 83.7 \\
\hline 4 & 6 & 10.9 & 14.0 & 97.7 \\
\hline 7 & 1 & 1.8 & 2.3 & 100.0 \\
\hline Total V. & 43 & 78.2 & 100.0 & \\
\hline Lost & 12 & 21.8 & & \\
\hline Total & 55 & 100.0 & & \\
\hline Mean & 2.26 & \\
\hline Median & 2 \\
\hline Typical deviation & \multicolumn{3}{|l}{} \\
\hline Mode & 255 \\
\hline
\end{tabular}

Fig 1. Company attitude

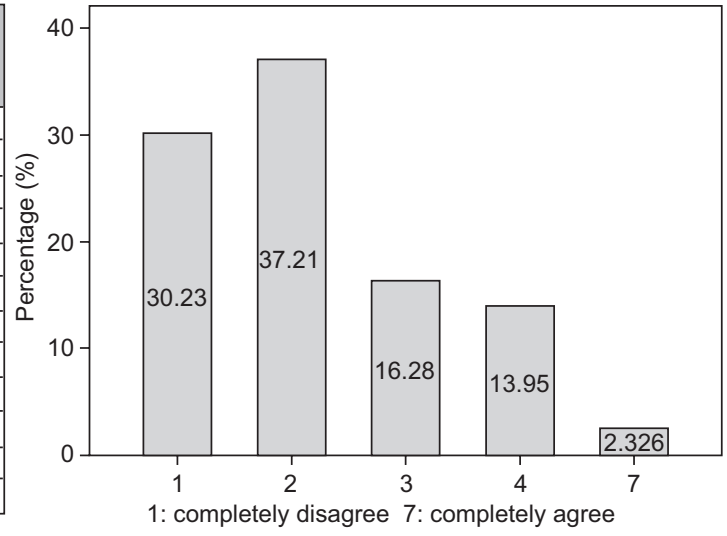

1: completely disagree 7 : completely agree

Multinational-transnational companies appropriate the environment through their resources but not their actual impacts and consequences

\begin{tabular}{|l|c|c|c|c|}
\hline & Freq. & Percentage & $\begin{array}{c}\text { Valid } \\
\text { percentage }\end{array}$ & $\begin{array}{c}\text { Accumulated } \\
\text { percentage }\end{array}$ \\
\hline 3 & 1 & 1.8 & 1.9 & 1.9 \\
\hline 4 & 4 & 7.3 & 7.7 & 9.6 \\
\hline 5 & 7 & 12.7 & 13.5 & 23.1 \\
\hline 6 & 14 & 25.5 & 26.9 & 50.0 \\
\hline 7 & 26 & 47.3 & 50.0 & 100.0 \\
\hline Total V. & 52 & 94.5 & 100.0 & \\
\hline Lost & 3 & 5.5 & & \\
\hline Total & 55 & 100.0 & & \\
\hline Mean & 6.15 & & \\
\hline Median & 6.5 & & \\
\hline Typical deviation & 1.055 & \\
\hline Mode & 7 & \\
\hline
\end{tabular}

Fig. 2. Appropriation of resources

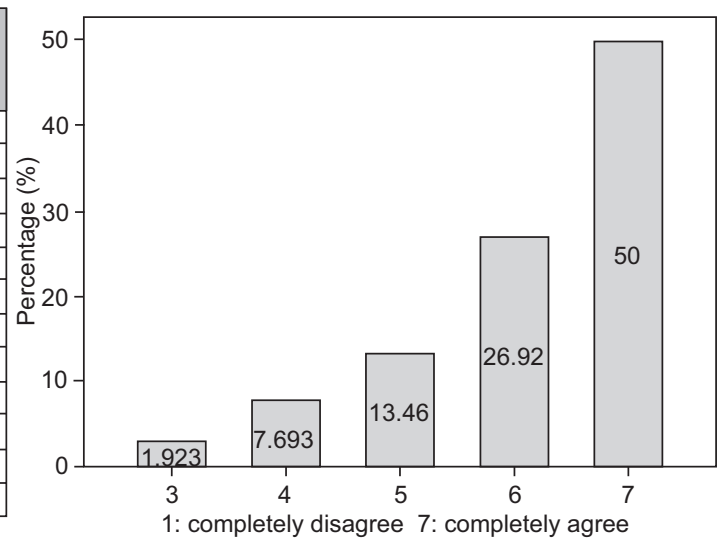

that I do not trust the motivations of many of these industries -textiles, foodstuffs- whose background involves immediate profits for their shareholders, and this is their only concern".

As a first approximation, the carbon and water footprints must be established. Salas and Condorhuaman (2014, p.25) delimit this: "A garment-producing textile company (textile and apparel processes) offers its customers climate- or carbon-neutral products as part of their interest in marketing their products in the green market." Climate neutral means that greenhouse gas (GHG) emissions are minimized and neutralized throughout the value chain. For this reason,

$\mathrm{CO}_{2}$ emissions must be inventoried throughout the value chain to avoid a lack of $\mathrm{CSR}^{8}$. TNCs should avoid the use of anemic or ad hoc legislations. As an example and bearing in mind the connection between the oil industry and its derivatives with the textile industry, Heede (2014) points out that Chevron, a leading company in the energy sector (petroleum), has sent more emissions into the atmosphere than the sum of all African countries put together since 1850, not including South Africa, and almost two thirds of historical carbon dioxide and methane emissions can be attributed to just 90 organizations. According to Breathelife $2030^{9}$ (2018), $92 \%$ of the global

\footnotetext{
${ }^{8}$ The International Framework Agreement of the IKEA business group establishes commercial efficacy as a requirement for enabling compliance with certain environmental and labor standards at the global level.

${ }^{9}$ Initiative of the World Health Organization and the United Nations.
} 
population on an urban and rural scale live in areas with higher atmospheric pollution levels than those recommended by the $\mathrm{WHO}$, and these contaminants are the principal causes of many common diseases. As an example, atmospheric pollution is responsible for $7 \%$ of lung cancer deaths, $18 \%$ of COPD (lung disease) deaths, $20 \%$ of stroke deaths, and $34 \%$ of deaths caused by heart disease.

With respect to the information received and analyzed on the answers to the question "Multinationaltransnational companies appropriate the environment through their resources but not their actual impacts and consequences", there was consensus among the participants when it came to tending towards the proposal. The sum of the values with the highest affinity were 5, 6 and 7, totaling $90.4 \%$. Values 1 and 2 received no affinity ranking. TNCs collect natural resources but not the real consequences of the use and transformation of these (Kant, 2012). For this, the private particularities of TNCs are transformed and legitimized as public or state interests, regulating in favor of trade, even over impacts and environmental sequelae (Underhill, 2016), thus fostering an unsustainable textile industry model (Luz 2007).

It is necessary to prosecute environmental crimes in a meaningful way (Fig. 3). With respect to the information received and analyzed on the answers to the question "Environmental crimes (discharge, toxic waste, undervalued risks, damage to ecosystems, living beings, etc.) should really be prosecuted, published, and sanctioned in accordance with damage caused in the past and in the future (sequelae)", according to the percentage of affinity recorded there was consensus among the participants when it came to tending towards the proposal. The sum of the values with the highest affinity were 6 and 7 , totaling $92.3 \%$.

We understand the vital nature of delimiting the consequences of textile production as well as the medium and long-term sequelae of its industrial developments (Azom et al., 2012). In fact, for UNECE (2018) "With regard to waste, $85 \%$ of textiles are sent to landfills, in other words, 21 billion tons each year." It is necessary to evaluate the considerable consumption of water in industrial textile processes, including the post-use discharge of a large quantity that is highly contaminated (Tüfekci et al., 2007). Activities that may be milimetrically legal but decontextualized and affected downwards by all the agents that make up the textile network such as TNCs, governments, certifiers, chemical companies, lobbies, subordinate workshops, and so on, should be articulated using international mechanisms capable of action and real containment at all points in the textile value chain, proposing, as an example, the creation of an International international Court court of Environmental environmental Justicejustice, or an International international Environmental environmental Inspectorate inspectorate for environmental crimes and abuse of global nature. The lack of justice in this field favors the loss of corporate legitimacy (Matthews et al., 1985; , Epstein, 1987, pp. 99-114). Iborra and Peris (2010, p.106) state that "[...] the legislation may be ambiguous or incomplete, in such a way that something may be legal but unjust according to the ethical maturity of a society." For this reason, the asymmetry of existing regulations, together with the lack of real legislation in line with

nvironmental crimes (discharge, toxic waste, undervalued risks, damage to ecosystems, living beings, etc.) should really be prosecuted, published, and sanctioned in accordance with damage caused in the past and in the future (sequelae)

\begin{tabular}{|c|c|c|c|c|}
\hline & Freq. & Percentage & $\begin{array}{c}\text { Valid } \\
\text { percentage }\end{array}$ & $\begin{array}{c}\text { Accumulated } \\
\text { percentage }\end{array}$ \\
\hline 1 & 1 & 1.8 & 1.9 & 1.9 \\
\hline 3 & 1 & 1.8 & 1.9 & 3.8 \\
\hline 4 & 2 & 3.6 & 3.8 & 7.7 \\
\hline 6 & 6 & 10.9 & 11.5 & 19.2 \\
\hline 7 & 42 & 76.4 & 80.8 & 100.0 \\
\hline Total V. & 52 & 94.5 & 100.0 & \\
\hline Lost & 3 & 5.5 & & \\
\hline Total & 55 & 100.0 & & \\
\hline Mean & 6.58 & & \\
\hline Median & 7 & & \\
\hline \multicolumn{2}{l|l}{ Typical deviation } & 1.144 & \\
\hline Mode & 7 \\
\hline
\end{tabular}

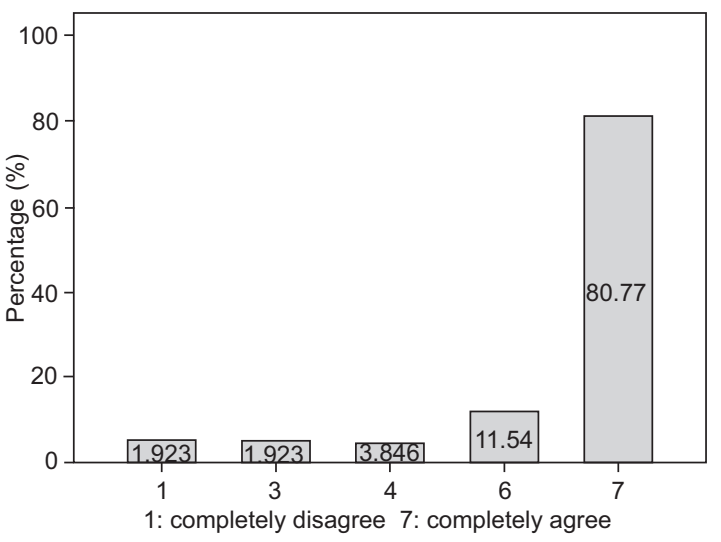

Fig. 3. Offenses and sequelae 
It is necessary to articulate some type of procedure that regulates "ecological debt"10

\begin{tabular}{|c|c|c|c|c|}
\hline & Freq. & Percentage & $\begin{array}{c}\text { Valid } \\
\text { percentage }\end{array}$ & $\begin{array}{c}\text { Accumulated } \\
\text { percentage }\end{array}$ \\
\hline 1 & 2 & 3.6 & 3.9 & 3.9 \\
\hline 3 & 1 & 1.8 & 2.0 & 5.9 \\
\hline 4 & 1 & 1.8 & 2.0 & 7.8 \\
\hline 5 & 5 & 9.1 & 9.8 & 17.6 \\
\hline 6 & 9 & 16.4 & 17.6 & 35.3 \\
\hline 7 & 33 & 60.0 & 64.7 & 100.0 \\
\hline Total V. & 51 & 92.7 & 100.0 & \\
\hline Lost & 4 & 7.3 & & \\
\hline Total & 55 & 100.0 & \\
\hline Mean & 6.25 & \\
\hline Median & 7 & \\
\hline Typical deviation & 1.422 & \\
\hline Mode & 7 \\
\hline
\end{tabular}

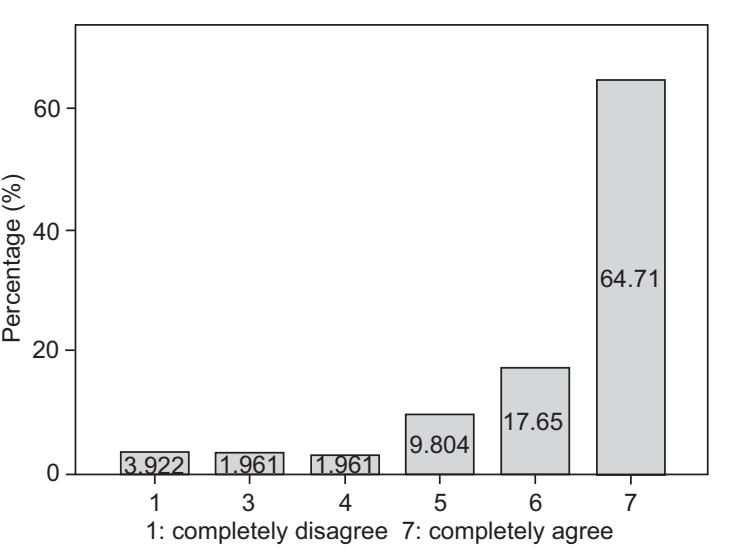

Fig. 4. Ecological debt

the volume of economic resources available to textile TNCs, has unpredictable consequences for human health and the environment. These circumstances can be amplified by "scientific research" according to particular interests, in many cases in the service of TNCs (Johns \& and Oppenheimer, 2018). This paradigm reveals unilateral CSR action to have no real control or enforceability, only the self-promotion of their interests. "State intervention is decisive, since it must provide an appropriate environment and basis for the development of socially committed companies" (Hernández et al., 2013, p. 310). Publicizing positive business aspects that have nothing to do with the company's main activity, or the consequences arising from its industrial production, will simply dress up the object of the CSR, in addition to testing the ability of society and the planet to resist.

It is necessary to develop ecological debt as a conceptual tool (Fig. 4). With respect to the information received and analyzed on the answers to the question "It is necessary to articulate some type of procedure that regulates "ecological debt", according to the percentage of affinity collected there was consensus among the participants when it came to tending towards the proposal. The sum of the values with the highest affinity were 5, 6 and 7, totaling $92.1 \%$.

The concept of ecological debt recognizes the interconnections between society, nature, and the economy, including the impact on sustainability and climate change. In parallel, divisions and challenges derive from the accumulation of capital (Warlenius et al., 2015, p. 28). According to Alier (2015), "[...] there are environmental liabilities and debt for climate change that the world's rich never pay. The consequences of financial debts are real but have been produced more artificially, and, in many cases, the debts per $s e$ are more fictitious. However, the debts generated by environmental damage and the negative effects of climate change are very real", and this is not the only issue. Would it be responsible and ethical to wipe the slate clean, and make everyone pay the same when not everyone is equally polluting, or works to the same ends? Obviously no. The current contribution to global warming of countries such as India or China is notorious; however, environmental responsibility cannot be attributed solely to developing countries. We need to quantify which countries were successful in the Industrial Revolution, in the mid-eighteenth century, through their innovation and daring, but also due to an unlimited use of natural resources, and the subsequent consequences generated. To do this, we propose a retroactive quantification of the ecological debt, including its effects on the budgets of each State. This circumstance will generate an objective and reliable predictor that can be applied to States.

Endocrine disruptors merita specialmention(Fig.5). These substances must be completely evaluated and identified. With respect to the information received and analyzed on the answers to the question "EDCs (endocrine disrupting chemicals) need to be identi-

\footnotetext{
${ }^{10}$ The ecological debt, according to J. Martinez Alier (2004), is the debt accumulated by the countries of the North to the countries of the South for two reasons. In the first place, exports of primary products at very low prices, that is to say, without including the environmental damage produced in the place of the extraction and processing, and pollution on a global scale. In the second place, is the occupation of free or very cheap of environmental space (atmosphere, water or land) to deposit the wastes of production
} 
The EDCs (endocrine disrupting chemicals) need to be identified, regardless of whether they are used as pesticides, biocides, in cosmetics, food packaging, toys for children, or in other products.

\begin{tabular}{|l|c|c|c|c|}
\hline & Freq. & Percentage & $\begin{array}{c}\text { Valid } \\
\text { percentage }\end{array}$ & $\begin{array}{c}\text { Accumulated } \\
\text { percentage }\end{array}$ \\
\hline 1 & 1 & 9.1 & 9.1 & 9.1 \\
\hline 6 & 1 & 9.1 & 9.1 & 18.2 \\
\hline 7 & 9 & 81.8 & 81.8 & 100.0 \\
\hline Total V. & 11 & 100.0 & 100.0 & \\
\hline Total & 7 & 100.0 & & \\
\hline \multicolumn{5}{|l}{} \\
\hline Mean & 6.36 \\
\hline Median & 7 \\
\hline Typical deviation & 1.804 \\
\hline Mode & 7 \\
\hline
\end{tabular}

Fig. 5. Disruptors fied, regardless of whether they are used as pesticides, biocides, in cosmetics, food packaging, children's toys, or in other products", according to the percentage of affinity collected there was consensus among the participants when it came to tending towards the proposal. The sum of the values with the highest affinity were 6 and 7 , totaling $90.9 \%$.

Romano (2015), an expert on risks and hormone disruptors, states that "in the case of textile products, European regulations only require companies to inform consumers of the presence, in their articles, of any of the substances included in the REACH candidate list (about 160 substances), whenever consumers ask. There is no obligation to include this information on the label." Endocrine disruptors have the capacity to alter normal hormone function and balance (Fernández et al., 2007; , Olea, 2009; , Jiménez and Kuhn, 2009), affecting embryo development; they intervene as unauthorized agents in the communicative process between hormones and cells (receptors), distorting the usual way of working and adopting a catalytic function (both through excess and lack). In many cases, they mask the action of the hormones themselves and cause the opposite effect to that of the typical hormone function; or they alter synthesis and normal metabolism, among other aspects, generating unpredictable consequences. For Romano (2015):

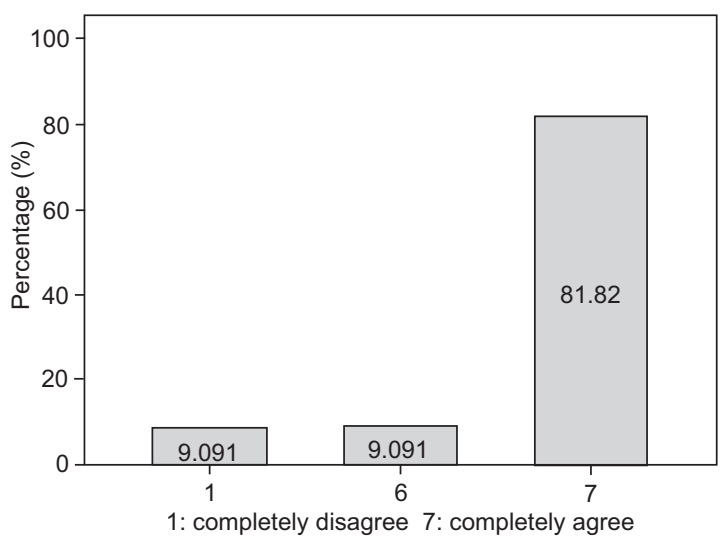

Spanish and European regulations allow the use of all chemical substances that are not restricted. In other words, they may be used as long as they have been shown not to cause an unacceptable risk to health and/or the environment. Demonstrating this involves a lengthy process of risk assessment, where the Commission or a Member State should be sufficiently concerned about the effects of the substance to prepare a restriction dossier.

The use of chemical compounds for which the health effects are unknown, or where there is evidence of them affecting animals and humans, cannot be considered necessary collateral damage for scientific advance (Fig. 6). With respect to the information received and analyzed on the answers to the question "The use of chemical compounds for which the health effects are unknown, or where there is evidence of them affecting animals (or humans), can be considered necessary collateral damage for scientific advance", according to the percentage of affinity collected there was consensus among the participants when it came to tending against the proposal. The sum of the values with the highest affinity were 1 and 2, totaling $100 \%$.

Today there is great accessibility to chemical substances ${ }^{11}$, as Marti Valls (2011) points out. Sometimes they are used legally as they are not

\footnotetext{
${ }^{11}$ J. M. Valls, in the text Pollution and health, of 11/21/2011, indicates that "today 100,000 chemical substances are used, among which around 4,000 to 8,000 are suspected to be toxic. The general environment and the domestic environment in homes and workplaces, are increasingly contaminated by a greater number of substances; it is estimated that up to $45 \%$ of the food we consume contains toxic waste. Of the 3,000 chemical products we use the most, the toxicity is not known for $85 \%$. This growing environmental pollution increasingly affects the quality and sustainability of the environment and the health of living species and humans."
} 
The use of chemical compounds for which the health effects are unknown, or where there is evidence of them affecting animals (or humans), can be considered necessary collateral damage for scientific advance

\begin{tabular}{|l|c|c|c|c|}
\hline & Freq. & Porcentage & $\begin{array}{c}\text { Valid } \\
\text { percentage }\end{array}$ & $\begin{array}{c}\text { Accumulated } \\
\text { percentage }\end{array}$ \\
\hline 1 & 9 & 81.8 & 81.8 & 81.8 \\
\hline 2 & 2 & 18.2 & 18.2 & 100.0 \\
\hline Total V. & 11 & 100.0 & 100.0 & \\
\hline Total & 7 & 100.0 & & \\
\hline \multicolumn{5}{|l|}{1.18} \\
\hline Mean & 1 \\
\hline Median & \multicolumn{4}{l}{} \\
\hline Typical deviation & \multicolumn{4}{l}{} \\
\hline Mode & 1 \\
\hline
\end{tabular}

Fig. 6. Origin of chemical substances prohibited in certain countries ${ }^{12}$, but this is ethically questionable. Additionally, it is worth noting the existence of substances identified in textiles such as quinoline (a compound involved in dye creation), which is possibly carcinogenic to humans and a wastewater contaminant, as well as a problem for both public health and the environment (Luongo et al., 2014). Some substances are banned in Europe or the USA ${ }^{13}$, but when textile garments are analyzed they may contain these, including lead or endocrine disruptors, which researchers already warn us about in their studies ${ }^{14}$. Silver nanoparticles are antimicrobial substances used to inhibit malodor bacteria; these can be released in garment washing processes and subsequently absorbed by plants (Colman, et al., 2013). It should be noted that toxins from textiles can

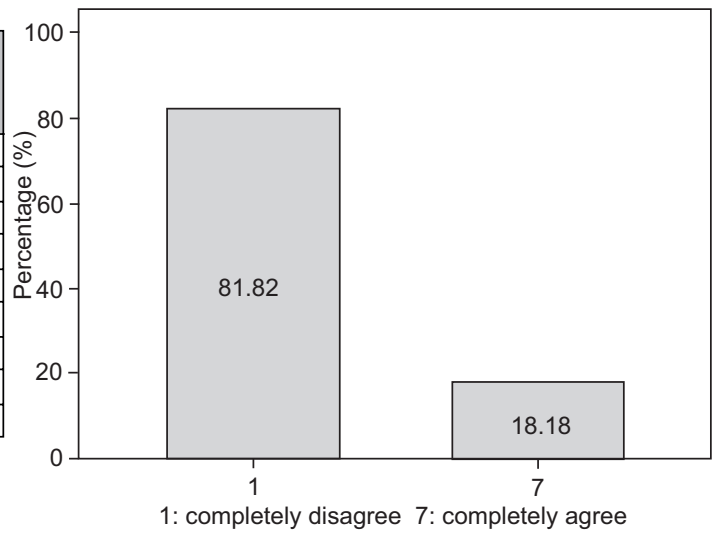

be incorporated into the body through the skin and via inhalation (Ibarluzea et al., 2016, p.2). There is enough evidence to suggest that these garments come from certain countries, already processed by means of labor and industrial practices that would never be allowed in other, advanced countries. According to the Textile and Clothing Information Center, Cityc (2015), "The problem lies in the varying environmental legislation in different countries. In the EU, there is REACH (Registration, Evaluation, Authorization, and Restriction of Chemicals) legislation. These regulations are very rigorous when it comes to chemical products, but REACH does not apply to imports from other areas, with the exception of products that are totally banned due to their harmful effects on health".

\footnotetext{
12“'As no limits have been established for the concentrations of NP/NPE [nonylphenol and nonylphenol ethoxylates] in imported textiles, these substances may appear in clothing and textile products imported from countries outside the EU, where there are no limits on their use in the manufacturing process." Text from the Danish Environmental Protection Agency. Consulted in 06/2016.

${ }^{13}$ List of restricted substances (LRS) created by a special working group of the American Apparel \& Footwear Association (AAFA). The LRS is aimed at providing clothing and footwear companies with information on the rules and laws that restrict or prohibit certain chemicals and substances in home textiles, clothing, footwear, and products from around the world.

${ }^{14}$ The Madrid Statement on Poly and Perfluoroalkyl Substances (PFASs), a text published by A. Blum et al. through Environmental Health Perspectives on 1/05/2015.

-Wash before use; unwashed clothes may contain formaldehyde, for which it is indicated: "substances such as formaldehyde and many other allergenic compounds are used in fabrics for a variety of reasons, such as to help prevent creasing and shrinkage" and "about $9 \%$ of the US population is so sensitive to formaldehyde that even low-level exposure may be enough to trigger an uncomfortable rash, or a severe allergic reaction [despite meeting the legal minimum, see the GAO report]" text prepared by Consumer Reports on 12/11/2010. -The professor and dermatologist from Columbia University Medical Center, D. Belsito, recommends washing clothes at least once before wearing them for the first time. If not, the formaldehyde resin that many garments contain can cause, "allergic contact dermatitis and irritant contact dermatitis", from the text entitled "Do You Need to Wash New Clothes Before Wearing Them?", prepared by H. Mitchell for The Wall Street Journal, on 19/05/2015.

-"Allergic contact dermatitis from formaldehyde resins in permanent press clothes: an underdiagnosed cause of generalized dermatitis." Text by J.F. Fowler et al., 1992.

-“Textile dermatitis in patients with contact sensitization in Israel: a 4-year prospective study.” Text by A. Lazarov, $09 / 2004$.
} 


\section{CONCLUSIONS}

The results of this research are of interest to consumers, public organizations, all kinds of counterpowers - such as NGOs and free thinkers - and, in particular, for textile TNCs.

The analysis undertaken evidences the critical, delicate environmental situation aggravated by the action of man (Fig. 1). The main environmental problems caused by current textile production can be listed as atmospheric and water pollution, a high toxicity level, and the generation of solid waste. We should note the ad hoc use of weak legislation that is not able to contain the asymmetries present through existing legislation. The life of society is marked by an unlimited production rate, even though it is well-known that natural resources are limited (Van der Ploeg, 2011). For this reason, the collection of resources must be regulated, in addition to the real consequences highlighting the inequality in growth, price effects, instability, poverty, unstable consumption, asymmetric exploitation rights, and so on (Rossignolo, 2015) (Fig. 2).

Social and business trends are submerged in publicized business developments. Everything must have impact, politics, the media, academic studies, and so on, which is why companies prioritize this type of action through CSR policies - and marketing - in order to achieve their goals, the long-awaited impact. For this reason, they make their clients and potential consumers - shortly, also voters - aware of their actions and commitment to the environment, despite the fact that society's position is abundantly clear. Concessions are no longer made for the effect on the environment and the continuous over-exploitation it is subjected to. Today it is not possible to defend the environment with the same weapons the large corporations use, due to their influence, power, and economic resources (Ziegler, 2013). According to Oxfam Intermon (2016, p.26):

The actors $[\ldots]$ have done their utmost to prevent the adoption of laws aimed at improving transparency in relation to the benefits obtained by extractive industries and improving accountability. The American
Petroleum Institute (API), one of the main detractors of these measures, dedicated at least 360 million dollars to fund lobbying activities to influence the US government between 2010 and 2014 .

Even though it is possible to procure impact - and followers - without situations improving, environmental crimes must be prosecuted in a meaningful way, proportional to the damage caused and its sequelae $^{15}$, despite the legal tightrope walking that exempts TNCs through the commercialization of justice and regulatory dysfunction. Abuses by TNCs must be audited proportionally to the damage caused (Fig. 3). For Gógova (2015), a researcher and expert in economic intelligence:

We can take a good lesson from animal life: they dedicate themselves to observing their habitat and the behavior of other animals, and to detecting patterns with which they establish the basis of their survival. Until we understand this, we will not have learned much: the environment surrounding us is as important as, or more important than, our characteristics as a company.

A system of action can, and should, establish a protocol of mandatory compliance that balances the regulatory asymmetry and the abuse committed by textile TNCs and governments, as, on occasion, countries that are tremendously rich in natural resources are depleted to exhaustion, being turned into basic States, in addition to outsourcing waste and all kinds of risks to these places in many cases (Grzybowski, 2012, p.119) ${ }^{16}$, de facto establishing impoverished growth. Hence, as an approximation to correct this, the following action guidelines prepared by the authors are proposed based on the interviews carried out with the experts:

1) Establishment of ecological debt (Fig. 4) as a minimum measurement of regulatory symmetry.

2) Accountability by managers, not only to shareholders. TNCs are legal entities subject to the rule of law, a circumstance that must be extended to the subjects that drive a company towards the abyss (being able to generate astronomical benefits while at the same time having cyclopean consequences for the environment). Double indictment - civil and

\footnotetext{
${ }^{15}$ Oil spill clean-up in the Niger Delta will take at least 30 years, according to information from Amnesty International UK "Shell Profits Won't Count the True Cost of Niger Delta Oil Spills", from 24/04/2015.

${ }^{16}$ According to L. Grzybowski "The growing internationalization of exchanges also elicits the fear of 'environmental dumping', through the delocalization of the most polluting industries to countries that have no environmental standards, or, at least, where they are more flexible. This risk comes simultaneously from both the liberalization of trade flows and capital flows. In any case, with or without dumping, the increasing economic competition makes companies worry less about the effects of their activities. And, at the moment, no regulatory body is incapable of imposing common standards.” From An Atlas of Globalization, p.119, 2012.
} 
criminal - for companies and managers is one of the pivotal points of CSR precepts. With no legality and effective security, business actions and their ethics are not credible.

3) Delimitation and specification of business developments at the global level. This should include both the sequelae generated by textile garments in the manufacturing processes (as well as inadvertent exposure), and in the mitigation mechanisms when obtaining permits, patents, homologations, certifications, tax exemptions for hiring, and so on. There is no possibility of hiding behind scientific advance to justify any type of collateral damage (Fig. 6).

4) Identification and real publication of $100 \%$ of the components making up textile products and this made available to the public authorities who, together with the scientific community (not only the official one, protected by the big brands), must evaluate - and monitor - the risks and alternative studies (with fewer resources but a higher impact for health). The use of endocrine disruptors stands out (Fig. 5).

5) Calculation of the carbon footprint for each garment put on the label, including the transport of that piece, the procurement, and external transformation of the materials necessary for its production. A QR code would be sufficient to solve the foreseeable lack of space claimed.

6) The externalization of risks (chemical, radioactive, environmental, etc.) produced by textile production processes, cannot be subcontracted to poorer countries, with no resources, which in many cases have high rates of corruption or failed states in the shadow of governments eager for investment, without reliable national legislation and with a lack of international organizations to ensure this. A list of prohibited and permitted production activities must be drawn up - that may be revised - by countries lacking, in many cases, the means to develop this with technical and democratic guarantees.

7) Extension of the competencies of the International Criminal Court over financial and environmental crimes in an extraterritorial manner, including the entire value chain (precedents include the UN Convention on the Law of the Sea). Currently, only State cases can be brought to the Court of International Justice, not those from civil society, a circumstance that turns this organization into a counter-figure in the defense of citizens' rights. In the same way, joint and several liability should be established for all the interveners and necessary cooperators.

8) Establishment of a biographic card as a public document, reviewable and extendable by public authorities, which can reflect sanctions, ratification of ILO conventions, knowledge of the entire production chain, not necessarily the names - they could be codes - but that they respect and promote the human rights, the real protection of the natural resources and of living beings that could be affected by their production.

9) Democratization of the composition of groups of experts formed by international organizations, with the purpose of avoiding pressure, bribes, irradiation by TNCs with particular interests, and so on, in order to improve transparency. An international resolution, or member of the panel of experts, can be vetoed if $25^{17}$ independent experts from the area with no financial interest in the purpose of the resolution challenge it. There are tools, such as the sending of anonymous documents, encryption, and so on, that allow the anonymous evaluation of texts by the scientific community and the issue of rulings in record time while maintaining direct anonymity.

10) Free Trade Agreements must be proposed to the legislative chamber of each country. A qualified majority is the minimum that will be required for approval. In addition, it should include a favorable independent report (prepared by an international public body), which encompasses the environmental impact of the treaty, as well as the tools and means necessary to reverse this in case of non-compliance or detection of sequelae deriving from its activity, indicated by the scientific community in their studies. The logical advance of the times and scientific evidence enable mechanisms to be established that readapt to new inverse realities. Free trade agreements should be back-dateable using the mechanism in point 9 .

11) Compliance with and promotion of binding legislation by States, as well as the adoption of this, with independence of the tailor-made free-trade agreements developed between TNCs and governments eager for investment, that exempts them. It is essential to leave self-imposed impact actions for the internal corporate news bulletins of TNCs. As indicated by Gómez Isa (2006, p. 60) "despite the wind generators that appear

\footnotetext{
${ }^{17}$ As an example, in the Delphi technique, Ruiz Olabuénaga et al. (1989) indicate between ten and thirty participants. Professor Landeta (2002) indicates that, for operational reasons, it is not recommended that this number exceeds fifty. Example of the Delphi technique elaborated by Luque et al. (2016b).
} 
in their ads" (associating their image with nature, ecology, and well-being), this does not diminish the opportunistic and image-washing ends.

12) Greater responsibility on the part of public powers (and citizen control of these), implementing the capacity to halt a textile/chemical industrial activity when an independent scientific study warns, by means of indicators, evidence, or reliable conclusions on certain latent risks, and/or manifests generated by the use of certain chemical substances or business practices. This includes the deliberate and uncontrolled expulsion of chemical substances to the natural environment through the obsolete legislation established. It is necessary to redirect the burden of proof towards textile TNCs, which must prove that the use of certain substances is harmless, and not world-class scientific experts with scant resources. The compliance with and use of antediluvian legislation, knowing that there are more rigorous, up-to-date laws with greater guarantees for human health, make TNCs jointly responsible, leading to criminal action against them and their facilitating elements (lobbies, corrupt governments).

13) Courts to which textile textile TNCs are submitted, prioritizing national and public jurisdiction instead of arbitrations such as ICSID or UNCITRAL, in order to not deprive States of competencies and legitimacy. A circumstance that must be decisive when establishing specifications in public purchases, a less expensive product cannot be the only variable taken into account.

14) Establishment of an environmental citizen unit supported by all the UN member countries with the capacity to act in the face of environmental catastrophes. Article 7, Paragraph 1k of the International Criminal Court is broad enough to include ecocide crimes.

15) Inclusion of the financial cost caused by the environmental damage to be included in the accounts of each State.

\section{REFERENCES}

Alier J. M. (2015). El concepto de crecimiento verde es absurdo, es el súper oxímoron [on line]. Retrieved from http://www.lamarea.com/2015/03/11/el-concepto-decrecimiento-verde-es-absurdo-es-el-super-oximoron/. (M. R. Rico, Interviewer) Lamarea.com 11/03/2015. Applegate L. M. (1994). Managing in an Information Age: Transforming the Organization for the 1990s. North Holland. Working Conference on Information Technology and New Emergent Forms of Organizations:
Transforming Organizations with Information Technology, 15-94. DOI: 10.1145/186281

Arias M. (2003). Metodologías de investigación emergentes en economía de la empresa. Papers Proceedings 2003, XVII Congreso Nacional XIII Congreso Hispano-Francés AEDEM,Université Montesquieu Bordeaux IV, 19-28.

Azom M., Mahmud K., Yahya S., Sontu A. and Himon, S. (2012). Environmental Impact Assessment of Tanneries: A Case Study of Hazaribag in Bangladesh. International Journal of Environmental Science and Development. 3, (2) 152.

DOI: $10.7763 /$ ijesd.2012.v3.206

Barroso F. (2008). Ganancia máxima o ganancia óptima. Desarrollo Empresarial. XI (110) 35-38.

Berrón G. (2015). Interview collected on Towards Outsourcing Limits and Logistic Processes within Developing Countries: Ethics or Aesthetics. Own documentation extracted from a DELPHI analysis, Published Doctoral Dissertation/ interviewed by A. Luque, on 7th May, 2015. King Juan Carlos University. Retrieved from https://dialnet.unirioja.es/servlet/ tesis? codigo $=249169$

Beton A., Dias D., Farrant L., T., G., le Guern Y., Desaxce M., . . Boufateh I. (2014). Environmental improvement potential of textiles (IMPRO-Textiles). European Commission. DOI: 10.2791/52624

Bevilacqua M., Ciarapica F., Giacchetta G., y Marchetti B. (2011). A carbon footprint analysis in the textile supply chain. International Journal of Sustainable Engineering. 4(1), 24-36. DOI: 10.1080/19397038.2010.502582

Boix I. (15 de 10 de 2016). Trabajo digno y sindicalismo en la globalización productiva. Retrieved from El Blog de Isidor Boix: http://iboix.blogspot.com/2016/10/ trabajo-digno-y-sindicalismo-en-la.html.

Breathelife2030. (20 de 05 de 2018). La contaminación atmosférica mata sin hacer ruido. Retrieved from http://breathelife2030.org/el-problema/a-quienesafecta/?lang=es

Browne M. (2015). Sources and Pathways of Microplastics to Habitats. Marine Anthropogenic Litter, 229-244. DOI: 10.1007/978-3-319-16510-3 9

Chapagain A., Hoekstra A., Savenije H. and Gautam R. (2006). The water footprint of cotton consumption: An assessment of the impact of worldwide consumption of cotton products on the water resources in the cotton producing countries. Ecological Economics. 60 (1), 186-203. DOI: 10.1016/j.ecolecon.2005.11.027

Chen H. and Burns L. (2006). Environmental analysis of textile products. Clothing and Textiles Research Journal. 24 (3) 248-261. DOI: 10.1177/0887302x06293065

Cityc. (2015). Interview collected on Towards Outsourcing Limits and Logistic Processes within Developing 
Countries: Ethics or Aesthetics. Own documentation extracted from a DELPHI analysis, Published Doctoral Dissertation/ interviewed by A. Luque, on 7th May, 2015. King Juan Carlos University. Retrieved from https://dialnet.unirioja.es/servlet/tesis?codigo $=249169$

Colman B., Arnaout C., Anciaux S., Gunsch C., Hochella M., Kim B., . . . Bernhardt E. (2013). Low concentrations of silver nanoparticles in biosolids cause adverse ecosystem responses under realistic field scenario. PloS One. 8(2) DOI: 10.1371/journal.pone.0057189

Costa J. (2007). El lado humano de la empresa. Signo y Pensamiento, 26 (51) 11-12.

Dalkey N. and Helmer O. (1963). An experimental application of the Delphi method to the use of experts. Management science, 9(3) 458-467.

DOI: $10.1287 / \mathrm{mnsc} .9 .3 .458$

del Rincón D., Arnal J., Latorre A. and Sans A. E. (1995). Técnicas de investigación en Ciencias Sociales. Madrid: Dikinson.

Dietz T. and Rosa E. (2002). Human dimensions of global environmental change. R. Dunlap and W. Michelson (Eds.). Handbook of Environmental Psychology. London, Greenwood Press.

Donaldson T. and Dunfee T. (1999). Ties that bind: A social contracts approach to business ethics . Boston: MA Harvard Business School Press.

DOI: $10.2307 / 3857756$

Duarte C. (2014). Diez razones científicas que te impedirán negar el cambio climático. Noticia elaborada por Rocio P. Benavente [on line]. Retrieved from. http:// www.elconfidencial.com/ tecnologia/2014-09-26/ diez-razones-cientificas-que-te-impediran-negar-elcambio-climatico_215232/ 26/09/2014.

Dussel E. (2015). Interview collected on towards outsourcing limits and logistic processes within developing countries: Ethics or aesthetics. Own documentation extracted from a DELPHI analysis, Published Doctoral Dissertation/ interviewed by A. Luque, on 7th May, 2015. King Juan Carlos University. Retrieved from https://dialnet.unirioja.es/servlet/tesis?codigo $=249169$

Epstein E. (1987). The corporate social policy process: Beyond business ethics,corporate social responsibility, and corporate social responsiveness. California Management Review 29 (3) 99-114. DOI: $10.2307 / 41165254$

Espino-Rodríguez T. (2003). El outsourcing y su influencia en los objetivos de la estrategia de operaciones. Una aplicación empírica. Cuadernos de Gestión 3 (1-2), 83-99.

European Commission. (2013). Sustainability of Textiles. Issue Paper 11. Brusells: European Commission Environment. https://ec.europa.eu/environment/industry/ retail/issue_papers.htm
European Environment Agency. (2016). Climate change, impacts and vulnerability in Europe 2016. Bruselas: Union Europea. DOI: 10.2800/534806

Fernández M., Olmos B. and Olea N. (2007). Exposure to endocrine disruptors and male urogenital tract malformations [cryptorchidism and hypospadias]. Gaceta Sanitaria 21 (6) 500-514. DOI:10.1007/978-1-60761-561-3_8

Fernández-Ballesteros R. (1995). Evaluación de programas: una guía práctica en ámbitos sociales,educativos y de salud. Madrid: Síntesis.

Gallezot P. (2012). Conversion of biomass to selected chemical products. Chemical Society Reviews 41 (4) 1538-1558.

DOI: $10.1039 / \mathrm{C} 1 \mathrm{CS} 15147 \mathrm{~A}$

Gógova S. (2015). Una experta en inteligencia, ex de Telefónica, cuenta cómo compiten las empresas. Noticia elaborada por Esteban Hernández [on line]. Retrieved from http://www.elconfidencial.com/alma-corazonvida/2015-10-09/una-experta-en-inteligencia-de-telefonica-cuenta-como-compiten-las-empresas_1053020/ $10 / 09 / 2015$.

Gómez Isa F. (2006). Empresas transnacionales y derechos humanos: desarrollos recientes. Lan Harremanak, Revista de Relaciones Laborales 55-94.

Grzybowski L. (2012). ¿Perjudica la mundialización al medio ambiente? (M. Sfeir, Ed.) El Atlas de las Mundializaciónes, 118.

Hamilton R. H. (1997). Outsourcing of information systems as strategic decision: An empirical analysis of the banking industry. Ph. D. Thesis, University of Georgia.

Heede R. (2014). Tracing anthropogenic carbon dioxide and methane emissions to fossil fuel and cement producers, 1854-2010. Climatic Change 122 (1-2) 229-241. DOI: 10.1007/s10584-013-0986-y

Hernández A. C., Conill L. Y., Hernández de Velazco J. and Ziritt G. (2013). Responsabilidad social empresarial y políticas públicas. Vol. XIX, No. 2, Abril - Junio 2013, pp. 309 - 321 FACES - LUZ ISSN 1315-9518

Herring A. (2014). Climate change research goes to the extremes. Retrieved from University of Northeaster: https://news.northeastern.edu/2014/07/climatechange-research-goes-to-the-extremes/ 13/04/2016.

Herva M., Franco A., Ferreiro S., Alvarez A. and Roca E. (2008). An approach for the application of the ecological footprint as environmental indicator in the textile sector. Journal of Hazardous Materials 156 (1) 478-487.

DOI: 10.1016/j.jhazmat.2007.12.077

Human Rights Watch. (2012). Toxic Tanneries: The Health Repercussions of Bangladesh's Hazaribagh Leather. Dhaka. DOI: 10.1163/2210-7975_hrd-2156-0750 
Human Rights Watch. (2015). Camboya: Trabajadores de la industria de la confección están desprotegidos [on line]. Retrieved from http://www.hrw.org/ es/news/2015/03/11/camboya-trabajadores-de-laindustria-de-la-confeccion-estan-desprotegidos $12 / 03 / 2015$.

Ibarluzea J., Aurrekoetxea J. J., Porta M., Sunyerc J. and Ballester F. (2016). La biomonitorización de sustancias tóxicas en muestras biológicas de población general. Gaceta Sanitaria. 30, Supplement 1, 45-54.

DOI: 10.1016/j.gaceta.2016.02.012

Iborra M. and Peris A. (2010). Reconstruyendo la confianza en las empresas mediante la responsabilidad social corporativa: Una ilustración en las cadenas de suministros del sector textil. GCG: Revista de Globalización, Competitividad y Gobernabilidad, 4(1). Retrieved from http://gcg.universia.net/articulo/150/ reconstruyendo-confianza-empresas-responsabilidadsocial-corporativa-ilustracion-cadenas-suministrossector-textil.html DOI: 10.19083/tesis/624218

International Labor Organization. (2015). Trabajo decente en las cadenas mundiales de suministro. Boletín Internacional de Investigación Sindical 7 (1-2).

IPCC. (2014). Cambio climático. Intergovernmental Panel on Climate Change. Retrieved from http://www.ipcc.ch/

Jacobson H. and Price M. (1990). A Framework for Research on the Human Dimensions of Global Environmental Change. Barcelona: Human Dimensions of Global Environmental Change Programme.

DOI: 10.1016/s0959-3780(02)00081-x

Jadhav J., Kalyani,D., Telke A., Phugare S. and Govindwar S. (2010). Evaluation of the efficacy of a bacterial consortium for the removal of color, reduction of heavy metals, and toxicity from textile dye effluent. Bioresource Technology V (101) 165-173. DOI: 10.1016/j.biortech.2009.08.027

Jiménez M. and Kuhn G. (2009). Toxicología fundamental. Madrid: Ediciones Diaz de Santos.

Johns D. and Oppenheimer G. (2018). Was there ever really a "sugar conspiracy"? Science 359 (6377) 747750. DOI: $10.1126 /$ science.aaq 1618

Kant R. (2012). Textile dyeing industry an environmental hazard. Natural Science 4 (1) 22-26.

DOI: $10.4236 / \mathrm{ns} .2012 .41004$

Kelley C., Mohtadib S., Canec M., Seagerc R. and Kushnirc Y. (2015). Climate change in the Fertile Crescent and implications of the recent Syrian drought. PNAS. Retrieved from http://www.pnas.org/content/ early/2015/02/23/1421533112.abstract.

DOI: $10.1073 /$ pnas. 1421533112

Labouze E., Le Guern Y. and des Abbayes C. (2006). Analyse de Cycle de Vie d'un Pantalon en Jean. Neuilly-sur-Seine (France): BIOIS.
Landeta J. (2002). El método Delphi. Una técnica de previsión del futuro. Barcelona: Ariel.

Landeta J. (2006). Current validity of the Delphi method in social sciences. Technological Forecasting y Social Change 73, 467-482.

DOI: $10.1016 /$ j.techfore.2005.09.002

Linstone H. and Turoff M. (1975). The Delphi method: Techniques and applications. Reading, MA: AddisonWesley, V. 29.

Lipovetsky G. (2013). El imperio de lo efímero. Barcelona: Anagrama.

Luna Huertas P., Infante Moro A. and Martínez F. (2006). Los Delphi como fundamento metodológico predictivo para la investigación en sistemas de información y tecnologías de la información (Is/It). Pixel-Bit. Revista de Medios y Educación 26, 89-112.

DOI: $10.12795 /$ pixelbit.2018.i52.09

Luongo G. (2015). Chemicals in textiles: A potential source for human exposure and environmental pollution. Stockholm: Stockholm University. Retrieved from http://www.diva-portal.org/smash/get/diva2:850089/ FULLTEXT02.pdf. ISBN 978-91-7649-225-3

Luongo G., Thorsén G. and Östman C. (2014). Quinolines in clothing textiles a source of human exposure and wastewater pollution? Analytical and Bioanalytical Chemistry. 406, 2747-2756.

DOI: $10.1007 / \mathrm{s} 00216-014-7688-9$

Luque A. and de Pablos C. (2016a). Factors that promote the lack of ethics in the production and logistics practices of transnational companies. Lan Harremanak. Revista de Relaciones Laborales 34, 336-370. http:// www.ehu.eus/ojs/index.php/Lan_Harremanak/article/ view/16578/14766.

Luque A., Hernández-Zubizarreta J. y de Pablos C. (2016b). Weaknesses in textile globalization processes and their relation to csr through a delphi analysis: ethics or aesthetics. Recerca. DOI: 10.6035/Recerca. 2016.19.3

Luque A., Hernández-Zubizarreta J. and de Pablos C. (2017a). Worldwide processes in the textile industry: relationship with social corporate responsibility through a Delphi analysis: Ethic or aesthetics. Regional and Sectoral Economic Studies 16-2, 105-132.

Luque A. (2017b). Promotion of transnational textile hyper-consumption: fashion and excess as leitmotif. Chasqui. Revista Latinoamericana de Comunicación. 134, 83-104.

Luque A. (2018). Corruption in the transnational textile industry: an exception or the rule? Empresa y Humanismo 21 (2) 123-184.

DOI: $10.15581 / 015 . X X I .2 .123-184$

Luz C. (2007). Waste couture: environmental impact of the clothing industry. Environmental Health Perspectives 115 (9) 449-454. DOI:10.1289/ehp.115-a449 
Martí-Valls J. (2011). La contaminación y la salud. Centre d'Anàlisi i Programes Sanitaris (CAPS). Retrieved from www.caps.cat $>$ caps $>$ la_contaminacin_y_la salud

Martínez-Piñeiro E. (2003). La técnica DELPHI como estrategia de consulta a los implicados en la evaluación de programas. Revista de Investigación Educativa 21 (2) 449-463. DOI: $10.2307 /$ j.ctv893hsg.19

Matthews H. (2015). Quantifying historical carbon and climate debts among nations. Nature Climate Change. DOI: $10.1038 /$ nclimate2774

Matthews J., Goodpaster K. and Nash L. (1985). Policies and persons: A casebook in business ethics. Nueva York: McGraw-Hill.

McKinsey Quarterly. (2007). http://www.mckinsey.com. Retrieved from "How companies think about climate change, a global survey" [on line]. http://www.mckinseyquarterly.com/How_companies_think_about_climate_change_A_McKinsey_Global_Survey_2099 23/03/2016.

Mengual S. (2011). La importancia percibida por el profesorado y el alumnado sobre la inclusión de la competencia digital en educación superior. Alicante: Departamento de Didáctica General y Didácticas Específicas de la Facultad de Alicante.

DOI: $10.15366 /$ didacticas2018.19.003

Morin E. (2015). Los dos humanismos. Le Monde Diplomatique, 2 [on line]. Retrieved from https://www.lemondediplomatique.cl/2015/12/los-dos-humanismos. html 14/09/2015.

Mulet J. (2015). Interview collected on Towards Outsourcing Limits and Logistic Processes within Developing Countries: Ethics or Aesthetics. Own documentation extracted from a DELPHI analysis, Published Doctoral Dissertation/ interviewed by A. Luque, on 7th May, 2015. King Juan Carlos University, Madrid, Spain. Retrieved from https://dialnet.unirioja.es/servlet/ tesis? codigo $=249169$

Muralidhar V., Ahasan M., Khan A. and Alam M. (2017). Basic occupational health services (BOHS) in community primary care: the MSF (Dhaka) model. BMJ case reports 2017. DOI: 10.1136/bcr-2016-218293

Murry J. and Hammons, J. (1995). Delphi: a versatile methodology for conducting qualitative research. Review of Higher Education 18 (4) 423-436. DOI: $10.1353 /$ rhe. 1995.0008

Nandy A. (2015). Un silencio muy largo. Le Monde Diplomatique, 1 [on line]. Retrieved from https://mondiplo. com/un-silencio-muy-largo 23/09/2016.

Olea N. (2009). Disruptores endocrinos: su presencia en el medio y efectos. Sociedad Española de Química Analítica (SEQA). Retrieved from https://digibug.ugr. es/handle/10481/24893
Oliveira G., Zanoni M., Palma D., Cardoso J., Ferraz E. and Chequer F. (2013). Textile dyes: dyeing process and environmental impact. Eco-friendly textile dyeing and finishing. InTech. Retrieved from https://www. intechopen.com/books/eco-friendly-textile-dyeingand-finishing/textile-dyes-dyeing-process-and-environmental-impact DOI: $10.5772 / 53659$

OSHA (2017). Administración de Seguridad y Salud de los EE.UU. [on line]. Retrieved from https://www. osha.gov/SLTC/hexavalentchromium/healtheffects. html 3/01/2017.

Oxfam Intermón. (2016). Una economía al servicio del 1\%. Retrieved from https://oxfamintermon.s3.amazonaws. $\mathrm{com} /$ sites/default/files/documentos/files/economiapara-minoria-informe.pdf DOI: 10.21201/2017.1350

Patry M., Tremblay M., Lanoie P. and Lacombe M. (1999). Why firms outsource their human resources activities: an empirical analysis. Scientific Series Cirano. Retrieved from http://www.cirano.qc.ca/pdf/ publication/99s-27.pdf. ISSN 1198-8177

Pawlik K. (1991). The Psychology of Global Environmental Change: Some Basic Data and an Agenda for Cooperative International Research. International Journal of Psychology 26 (5) DOI: 10.1080/00207599108247143

Pill J. (1971). The Delphi method: substance, context, a critique and an annotated bibliography. Socio-Economic Planning Sciences 5 (1) 57-71.

DOI: $10.1016 / 0038-0121(71) 90041-3$

Pinheiro H. M., Touraud E. and Thomas O. (2004). Aromatic amines from azo dye reduction: status review with emphasis on direct UV spectrophotometric detection in textile industry wastewaters. Dyes and pigments 61 (2) 121-139. DOI: 10.1016/j.dyepig.2003.10.009

Ramonet I. (2010). El capitalismo como origen del cambio climático. Barcelona: Fundación Alfons Comín.

Rhodes M. (1997). The Welfare State: Internal Challenges, External Constraints (M. Rhodes, P. Heywood and V. Wright Eds.) Developments in West European Politics 1, Macmillan Press.

DOI: 10.1007/978-1-349-25341-8 4

Rojas M., M'Zali B., Turcotte M. and Cooli M. (2006). Corporate social responsibility, the stakeholder approach and beyond: in search of theoretical explanations for "Doing well while Doing good". San Luis Potosí: Ponencia presentada en el X Congreso Anual de la Academia de Ciencias Administrativas A.C. (ACACIA).

Romano D. (2015). Interview collected on Towards Outsourcing Limits and Logistic Processes within Developing Countries: Ethics or Aesthetics. Own documentation extracted from a DELPHI analysis, Published Doctoral Dissertation/ interviewed by A. Luque, on 7th May, 2015. King Juan Carlos University, 
Madrid, Spain. Retrieved from https://dialnet.unirioja. es/servlet/tesis?codigo $=249169$

Rossignolo D. (2015). Efectos económicos y macrofiscales de los recursos naturales en América Latina. Santiago de Chile: CEPAL. DOI: 10.1787/888933685644

Ruiz-Olabuénaga J. and Ispizua M. (1989). La descodificación de la vida cotidiana. Bilbao: Universidad de Deusto.

Salas G. and Condorhuaman C. (2014). Huella de carbono en la industria textil. Revista Peruana de Química e Ingeniería Química 12 (2) 25-28. Retrieved from https:// revistasinvestigacion.unmsm.edu.pe/index.php/quim/ article/view/4314/3442

Senthilkannan S. (2015). Handbook of Life Cycle Assessment (LCA) of Textiles and Clothing. Cambridge: Woodhead Publishing Series in Textiles: $\mathrm{N}^{\circ} 172$. DOI: 10.1016/b978-0-08-100169-1.09002-x

Smith A. (2014). Fortune 500 companies spend more the $\$ 15 \mathrm{bn}$ on corporate responsibility [on line]. Retrieved from https://www.ft.com/content/95239a6e4fe0-11e4-a0a4-00144feab7de 12/10/2015.

Soriano I. (2015). Interview collected on Towards Outsourcing Limits and Logistic Processes within Developing Countries: Ethics or Aesthetics. Own documentation extracted from a DELPHI analysis, Published Doctoral Dissertation/ interviewed by A. Luque, on 7th May, 2015. King Juan Carlos University, Madrid, Spain. Retrieved from https://dialnet.unirioja. es/servlet/tesis?codigo $=249169$

Stern P., Young O. and Druckman D. (1992). Global Environmental Change. Understanding the Human Dimensions. Washington, D.C.: National Academic Press. DOI: $10.17226 / 1792$

Tüfekci N., Sivri N. and Toroz İ. (2007). Pollutants of textile industry wastewater and assessment of its discharge limits by water quality standards. Turkish Journal of Fisheries and Aquatic Sciences 7, 97-103. Retrieved from http://www.trjfas.org/abstract.php?id=319

Underhill G. (2016). Industrial Crisis and the Open Economy: Politics, Global Trade and the Textile Industry in the Advanced Economies. Basingstoke: Springer.

UNESCO. (2016). Informe de las Naciones Unidas sobre el Desarrollo de los Recursos Hídricos en el Mundo. Francia: UNESCO. DOI: $10.18356 / b 77$ e1f7d-es

United Nations Economic Commission for Europe (UNECE). (2018). Fashion and the SDGs: What role for the UN? Genova: ONU. Retrieved from https:// www.unece.org/fileadmin/DAM/ RCM_Website/ RFSD_2018_Side_event_sustainable_fashion.pdf. DOI: $10.18356 /$ afdbe $50 \mathrm{e}-\mathrm{en}$
University of Copenhaguen. (2009). Cambio Climático: Riesgos, retos y decisiones globales. Copenhaguen: International Alliance of of Research Universities.

University of Exeter (2017). Antarctica 'greening' due to climate change. Retrieved from http://www.exeter.ac.uk/ news/research/title_583908_en.html 18/05/2017.

Van der Ploeg F. (2011). Natural resources: Curse or blessing? Journal of Economic Literature. V.49(2), 366-420. DOI: 10.1257/jel.49.2.366

Vandevivere P., Bianchi R. and Verstraete W. (1998). Review: Treatment and reuse of wastewater from the textile wet-processing industry: Review of emerging technologies. Journal of Chemical Technology and Biotechnology. V. 72.4 , 289-302.

DOI: $10.1002 /$ (sici)1097-4660(199808)72:4\%3C289 ::aid-jctb905\%3E3.0.co;2-\#

Vélez-Pareja I. (2002). Decisiones de inversión enfocado a la valoración de empresas. Bogotá: CEJA.

Warlenius R., Pierce G. and Ramasar V. (2015). Reversing the arrow of arrears: The concept of "ecological debt" and its value for environmental justice. Global Environmental Change. 30, 21-30.

DOI: 10.1016/j.gloenvcha.2014.10.014

Watson C. (2015). Interview collected on Towards Outsourcing Limits and Logistic Processes within Developing Countries: Ethics or Aesthetics. Own documentation extracted from a DELPHI analysis, Published Doctoral Dissertation/ interviewed by A. Luque, on 7th May, 2015. King Juan Carlos University, Madrid, Spain. Retrieved from https://dialnet.unirioja. es/servlet $/$ tesis? codigo $=249169$

Welzer H. (2009). Les guerres du climat: Pourquoi on tue au XXIe siècle. París: Collection Folio actuel ( ${ }^{\circ}$ 152), Gallimard.

World Bank. (2013). ¿Qué significa el cambio climático para África, Asia y los pobres que viven en las zonas costeras? [on line]. Retrieved from http://www. bancomundial.org/es/news/feature/ 2013/06/19/ what-climate-change-means-africa-asia-coastal-poor 19/06/2013.

World Trade Organization. (2015). https://www.wto.org. Retrieved from Estadísticas del comercio internacional 2015 [on line]. https://www.wto.org/spanish/res_s/ statis_s/its2015_s/its15_toc_s.htm DOI: $10.30875 / 254006 \mathrm{c} 1$-es 19/06/2016.

Yuan Z. W., Zhu Y. N., Shi J. K., Liu X. and Huang L. (2013). Life-cycle assessment of continuous paddyeing technology for cotton fabrics. The International Journal of Life Cycle Assessment 18(3), 659-672. DOI: $10.1007 / \mathrm{s} 11367-012-0470-3$

Ziegler J. (2013). The New Masters of the World. Barcelona: Destino. 


\section{ANNEX I}

This research project would have not been possible without the participation of experts that have taken part in an altruist and disinterest way, 450 sheets of responses - quantitative and qualitative have been received from participants for academic discussion. Amongst other we mention to Fernando Oliván (Director of the Euromediterranean observatory, ex-member of the International Criminal Court an associate professor at the Sorbonne University and URJC), Isidor Boix (secretary for International Trading Action FITEQA-CC.OO), Octavio Granado (expert in public financing and ex-secretary of State in Social Security System), Michael Addo (researcher in the University of Exeter, Devon, UK and member of a group of work on firms and Human Rights in Nations), Gabriel Flores Sánchez (researcher from the Complutense Institute of International Studies), Aleida Hernández (researcher in the National Autonomous University in Mexico), Juan Andrés Cano (CEO in Value4Chain), María del Mar Maira Vidal (researcher in the Valladolid University), Rodrigo Martín (Researcher in the URJC, ex jury of the TSJM and member of the academic conseil in Gómez-Acebo \& Pombo), Alejandro Goldberg (researcher in CONICET), Amaya Apesteguía (OCU), Ibon Maza (BabyAuto), Enrique Dussel (researcher in the Autonomous University in Mexico and coordinator of studies in CEPAL and OIT), Jesús García Luengos (Coordinator for the RESET Research on Security and Transnational Governance think tank), Jordi Bonet (Professor in the UB in Public International Rights), José Manuel Pureza (researcher in the Coimbra University and CES, CPA referee and in United Nations on sea issues), Roberto Toscano (researcher of international relationships and SCR, apart from ex-ambassador of Italy in Iran and India), Juan Manzanedo (Ceo in LOGISFASHION), Juan Pérez Ventura (Ceo the World Order in the XXI century), Paula Alves (employee of Inditex group during 24 años and secretary of the Textile-Leather Industry FITAG-UGT) , Santi Mallorquí (Ceo in ORGANIC COTTON COLOURS), Martim Gemzell (WARONTWANT), Gema Gómez (Ceo SLOW FASHION SPAIN), Carmen Gómez-Cotta (ETHIC), Enrique Palazuelos Manso (Full time professor in Applied Economy in the Complutense University in Madrid), Michael Tamvakis (researcher of the Cass Business School), Eva García (ECOOLOGY), Alejandro Dulitzky (researcher in the San Martín National University), Juan Torres (Full time profesor in Applied Economy in Seville University and member of ATTAC scientific Comittee), Amparo Merino Segovia (researcher in the Castilla la Mancha University), Gonzalo Berrón (FES Fundación Friedrich Ebert), Alejandro Teitelbaum (writer, lawyer and representing the International Federation for Human Rights and the American Association of jurists in United Nations), Carmen Silla (JEANOLOGIA), Antonio Baylos (Full time professor in Work and Social Security Law)in Castilla la Mancha University), Álvaro Orsatti (CSA), Monika Kemperle (IndustriALL Global Union), Mariano Aguirre (director of Norwegian Peacebuilding Resource Centre NOREF in Oslo), Pablo José Martínez Osés (researcher and coordinator of the state campaign Zero Poverty and member of 2015ymas), Iñaki Barcena (Full time professor in Political Science in the Vasque Country University), Virginia Rondeel (BCN Sustainable Fashion), Marta Castells (CITYC), Enrique Guerrero Salom (lecturer and eurodiputy), Javier Chércoles (researcher in the Dhaka University and director of risks in the Associated British Foods plc), Esteban Kaipl (researcher in the Litoral University), Iratxe Arteagoitia \& Eva Kreisler (SETEM \& CLEAN CLOTHES CAMPAIGN), José Miguel Mulet (researcher in the Molecular and Cellular Plants Institute IBMCP, Valencia), Amanda Cattermole (CATTERMOLECONSULTING), Liliane Spendeler (FRIENDSOFLAND), Cheryl S. Watson (researcher in the University of Texas Medical Branch), Isabel Soriano (AITEX), Dolores Romano (independent researcher/Ecologists in action), Antonio Solé Cabanes (ASOLEGIN), Oscar Miralles (independent researcher), Xavier Giménez Font (researcher in Environmental Chemistry in Barcelona University), Raimon Guitart (researcher in toxicology in the Autonomous University in Barcelona), Ferran Ballester (coordinator of the area Ambient i Salut in the Upper Centre for Research in Public Health, CSISP), Stephane Horel (independent) and Carlos de Prada (Fodesam). 